\title{
Propagule Size and the Relative Success of Exotic Ungulate and Bird Introductions to New Zealand
}

\author{
David M. Forsyth ${ }^{1,2, *}$ and Richard P. Duncan ${ }^{3, \dagger}$
}

1. Centre for Biodiversity Research, Department of Zoology, University of British Columbia, Vancouver, British Columbia V6T 1Z4, Canada;

2. Landcare Research, P.O. Box 69, Lincoln 8152, New Zealand; 3. Ecology and Entomology Group, Soil, Plant, and Ecological Sciences Division, P.O. Box 84, Lincoln University, Canterbury, New Zealand

Submitted August 16, 1999; Accepted January 15, 2001

\begin{abstract}
We investigated factors affecting the success of 14 species of ungulates introduced to New Zealand around 1851-1926. The 11 successful species had a shorter maximum life span and were introduced in greater numbers than the three unsuccessful species. Because introduction effort was confounded with other life-history traits, we examined whether independent introductions of the same species were more likely to succeed when a greater number of individuals were introduced. For the six species with introductions that both succeeded and failed, successful introductions always involved an equal or greater number of individuals than unsuccessful introductions of the same species. For all independent introductions, there was a highly significant relationship between the number of individuals introduced and introduction success. When data for ungulate and bird introductions to New Zealand were combined, a variable categorizing species as ungulate or bird was a highly significant predictor of introduction success, after variation in introduction effort was controlled. For a given number of individuals introduced, ungulates were much more likely to succeed than birds.
\end{abstract}

Keywords: biological invasions, bird introductions, extinction, mammal introductions, ungulates.

The factors influencing the success of biological invasions have long interested ecologists (Elton 1958; Mooney and Drake 1986; Crawley 1987; Drake et al. 1989; Lodge 1993; Ruesink et al. 1995; Williamson and Fitter 1996). The number of individuals involved in the invasion, or "propagule

\footnotetext{
* E-mail: forsythd@landcare.cri.nz.

+ Corresponding author; e-mail: duncanr@lincoln.ac.nz.
}

Am. Nat. 2001. Vol. 157, pp. 583-595. (c) 2001 by The University of Chicago. 0003-0147/2001/15706-0001\$03.00. All rights reserved. size," has a strong theoretical basis for determining introduction success. Demographic stochasticity, the result of random and independent births and deaths, can lead to population extinction, the probability of which is inversely proportional to population size (Goel and Richter-Dyn 1974; Leigh 1981; Goodman 1987; Lande 1988, 1993, 1998; Legendre et al. 1999). The likelihood of extinction from random catastrophes and environmental stochasticity is also inversely related to population size (Hanson and Tuckwell 1978; Leigh 1981; Lande 1993). Thus, for any taxon, larger propagules can be expected to have a greater probability of successful introduction than smaller propagules. Comparisons of successful and unsuccessful introductions of insects (Beirne 1975; Ehler and Hall 1982; Hopper and Roush 1993; Memmott et al. 1998; Berggren 2001), birds (Griffith et al. 1989; Veltman et al. 1996; Green 1997; Wolf et al. 1998), and mammals (Crowell 1973; Ebenhard 1989; Griffith et al. 1989; Novellie et al. 1996; Wolf et al. 1998; Komers and Curman 2000) have identified increasing propagule size (or surrogates of propagule size) as a significant correlate of introduction success. Other factors associated with successful animal introductions have been habitat suitability (Novellie and Knight 1994) or quality (Griffith et al. 1989), an absence of migratory behavior (Veltman et al. 1996), plumage dichromatism (McLain et al. 1995; Sorci et al. 1998), a polygynous rather than a monogamous mating system (Legendre et al. 1999), and being introduced where fewer potential competitors (Ehler and Hall 1982; Moulton 1985; Moulton and Pimm 1987; Moulton and Lockwood 1992; Lockwood et al. 1993; Lockwood and Moulton 1994; but see Duncan 1997) or predators (Short et al. 1992; Schoener and Spiller 1995; Lovegrove 1996) were present.

Comparisons of invasion success have usually been conducted within broad taxonomic groups such as birds in Hawaii and New Zealand (Moulton and Pimm 1987; Veltman et al. 1996). Also of interest is the extent to which species in broad taxonomic groups might differ in their likelihood of introduction success (Williamson and Fitter 1996). Such differences could arise because taxa in different groups differ in traits likely to affect the probability of successful invasion (Lodge 1993; Ruesink et al. 1995). 
Modeling suggests that species with long life spans, relatively constant numbers over time, and high rates of population growth will have low probabilities of extinction (Richter-Dyn and Goel 1972; Leigh 1981). However, there have been few empirical tests of these predictions (Pimm et al. 1988; Ebenhard 1989; Schoener and Spiller 1992; Tracy and George 1992; Ryan and Siegfried 1994), and the relative importance of these life-history traits in determining invasion success is equivocal (Lawton and Brown 1986; Lodge 1993; Ruesink et al. 1995). Furthermore, since longevity, intrinsic rate of increase, and population variability are not independent life-history traits (Caughley and Krebs 1983; Gaillard et al. 1989; Stearns 1992), very different predictions can often be made about the invasion success of a taxonomic group. Because of their greater body size and longevity, large mammals should be more buffered from environmental extremes (Lindstedt and Boyce 1985) and consequently have a higher probability of successful invasion than most birds. Conversely, because of a low rate of population increase relative to birds, large mammals could take longer to attain population sizes at which extinction from environmental or demographic stochasticity is unlikely (Pimm 1991), thereby lowering their introduction success relative to birds. Clearly, quantitative comparisons are required before robust generalizations about the relative invasion success of different taxonomic groups can be made.

Mammals and birds have been frequently introduced to new locations (Long 1981; Lever 1994) with varying success (Williamson and Fitter 1996). The introduction of ungulate and bird species to New Zealand has been well documented (e.g., Thomson 1922; Donne 1924), and these records provide an opportunity to test hypotheses about the factors influencing invasion success in these two groups and to compare the outcomes. Recent analyses of exotic bird introductions to New Zealand have identified initial propagule size and the number of introductions (collectively, "introduction effort"), plumage dichromatism, and mating system as significant predictors of introduction success (Veltman et al. 1996; Williamson 1996; Duncan 1997; Green 1997; Sorci et al. 1998; Legendre et al. 1999). The factors influencing the success of ungulate introductions to New Zealand have not yet been investigated.

In this article, we compare the factors affecting the introduction success of ungulate and bird species introduced to New Zealand. The objectives of our study were twofold: first, to identify which life-history and/or ecological variables predict the success of 14 ungulate species introduced to New Zealand and to determine whether introduction effort was a factor influencing introduction success and, second, to determine whether species of ungulates and birds differed in their probability of success when introduced to New Zealand.

\section{Methods}

\section{Data Sources}

We searched the literature for information on the introduction of ungulates into North, South, and Stewart Islands ("New Zealand"). Our primary sources were Thomson (1922), Donne (1924), Logan and Harris (1967), and King (1990). The purpose of nearly all introductions was to establish wild populations for hunting (Thomson 1922). Introductions were made between approximately 1851 and 1926; thereafter, the importation of ungulates to New Zealand ceased, although some animals captured from established herds were released (King 1990). We did not include species introduced primarily as domestic livestock that subsequently became feral (Sus scrofa, Bos taurus, Capra hircus, Equus caballus, and Ovis avies) or two unsuccessful species for which there was no information on the number of introduction events or the number of individuals introduced (a "South American deer," species unknown, and Lama glama; King 1990).

Introductions were defined as "successful" if the species had wild populations in New Zealand in 1996 or previously had a self-sustaining wild population that was eradicated by hunting. Only one species, Axis axis, met the latter criterion. Introductions not meeting these criteria were termed "unsuccessful." There is uncertainty as to whether moose (Alces alces) were extant in New Zealand in 1996 (Davidson and Tustin 1990), but based on the evidence in Tustin (1998), we concluded that a population was present.

To determine whether introductions failed because species were introduced into areas that lacked suitable habitat, we quantified the propensity of each species to utilize 10 major habitat types in New Zealand (table 1). Each habitat was scored as 1 for "suitable" and 0 for "unsuitable" based on descriptions of each species' habitat use outside New Zealand (see table 1 for data sources). In addition, for the species introduced successfully to New Zealand, we assumed that habitats currently used by these species would have been suitable for introductions. We then identified the habitats that were available at the locations where species were introduced and determined whether species had been introduced to areas that lacked suitable habitat. We acknowledge the difficulty of determining whether habitat is "suitable" for an exotic species. However, we judged only one introduction of three Himalayan tahr to the Rotorua district (Donne 1924) to have been made into unsuitable habitat, and we excluded this introduction from our analyses. Our results were unchanged when this introduction was assumed to have been into suitable habitat.

We collected data on the following life-history traits (see table 2 for data sources): body mass of adult males and females $(\mathrm{kg})$, maximum life span of males and females (yr), youngest recorded age at which females wean young (yr), 


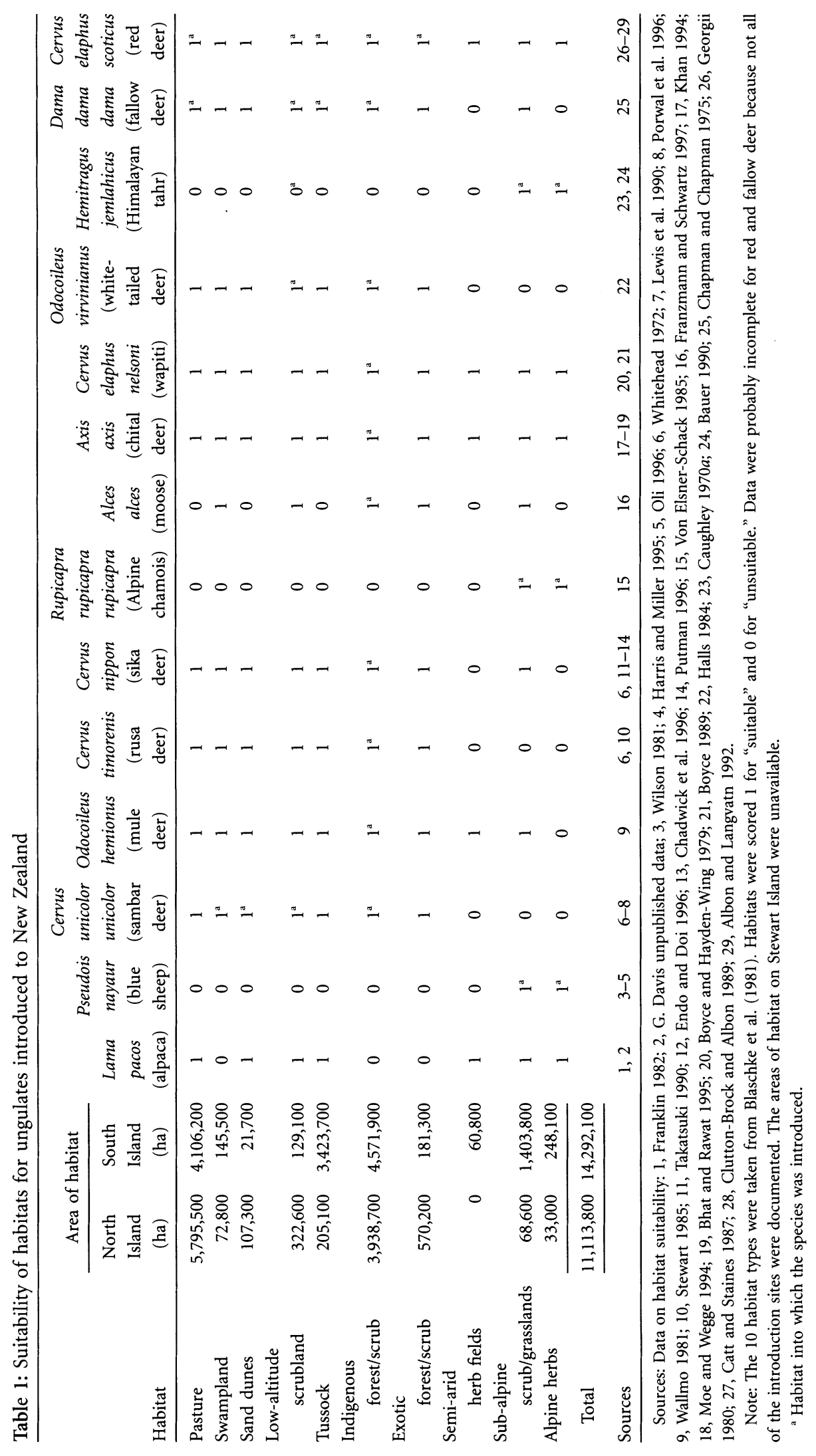


number of offspring born per adult female per annum, and maximum lifetime reproduction (the product of reproductive life span [maximum female life span minus age at first reproduction] and number of offspring born per annum). Mating systems were classified according to Weckerly (1998): "tending," males did not herd or follow more than two females simultaneously; "harem," males did herd more than two females simultaneously; and "territorial," males exhibited polygyny based on a territory defended against other males. The most common system was used for species exhibiting multiple mating systems (Weckerly 1998). We also categorized species as migratory (defined as consistent seasonal shifts of individuals between geographic areas; McCullough 1991) or nonmigratory.

Estimates of annual survival based on capture-markrecapture models are preferable to observed maximum life spans (Krementz et al. 1989), but these data were unavailable for most ungulates introduced to New Zealand. We caution that observed maximum life span represents a best-case survival estimate.

\section{Statistical Procedures}

Introduction success was used as the response variable in a logistic regression model with the remaining variables fitted individually as predictors. Body mass, maximum longevity, maximum lifetime reproduction, minimum number of introduction events, and minimum number of individuals introduced were $\log _{10}$ transformed, and dummy categories were constructed for mating system. A problem arose for two variables (maximum life span of males and minimum number of introduction events) in that the logistic regression model failed to converge because the model provided an exact fit to certain observations and so was overfitted (see Collett 1991, p. 82). We therefore tested whether successful and unsuccessful species differed in maximum male life span and number of introduction events using a Kruskall-Wallis approximate $\chi^{2}$ test. The problem of overfitting became acute when we attempted to model introduction success as a function of two or more predictor variables using multiple logistic regression. To overcome this problem, we used principal components analysis (PCA) to extract two axes that explained most of the variation in species traits. We included all $\log _{10}$-transformed variables except migratory tendency (because it contained missing values) in the PCA and then examined how successful and unsuccessful species were arranged along the first two PC axes.

It became apparent that the relationship between present-day status and introduction effort was confounded with other species traits. This makes it difficult to argue for a causal relationship between introduction effort and introduction success because that relationship could have arisen indirectly. Those species with traits that make them successful invaders may just happen to have been introduced more times and in greater numbers. We could overcome this problem by statistically controlling for the influence of other traits in multiple regression (e.g., Veltman et al. 1996) or by incorporating phylogenetic information into our analysis and thereby testing only for differences between closely related species that share potentially confounding life-history traits in common (Harvey and Pagel 1991). However, the small size and sparseness of our data set precluded either approach.

A better way of dealing with this problem is to investigate the outcome of independent introductions of the same species to different locations. If propagule size is a key factor influencing introduction success, then introductions of the same species to different locations should be more likely to succeed if a greater number of individuals are introduced. By comparing the outcome of independent introductions of the same species, we sidestep the problem that across-species comparisons are confounded with variation in life-history traits. We therefore collated the available data for independent introductions of each species to different locations in New Zealand and examined whether introductions that succeeded consistently involved more individuals than introductions of the same species that failed.

Complete data on the number of individuals involved in each introduction were available for all species except fallow deer (Dama dama dama) and red deer (Cervus elaphus scoticus). For this last species, data on the number of individuals were available for all introductions to a region of the northern South Island (Clarke 1971). We can discount two factors that could confound our analysis. First, when several introductions of the same species were made to the same location within a short space of time, we considered them to be a single introduction. The introductions that we considered were then sufficiently separated in time or space that they could be reasonably regarded as independent events. Second, people might have introduced more individuals to locations where they were more likely to succeed in the first place or, when they introduced a large number of individuals, may have modified the site to make success more likely. Although we lack data to test this possibility, the large majority of introductions occurred in unmodified indigenous habitats. Range expansions from successful introductions have also included sites where unsuccessful introductions of the same species (e.g., Himalayan tahr in the Southern Alps; Tustin 1990) or species with similar habitat requirements (e.g., expanding red deer and unsuccessful white-tailed deer at Takaka Valley; Challies 1990a; Davidson and Challies 1990) were made. At least in these cases, it is unlikely that habitat modifications or a lack of suitable habitat were 


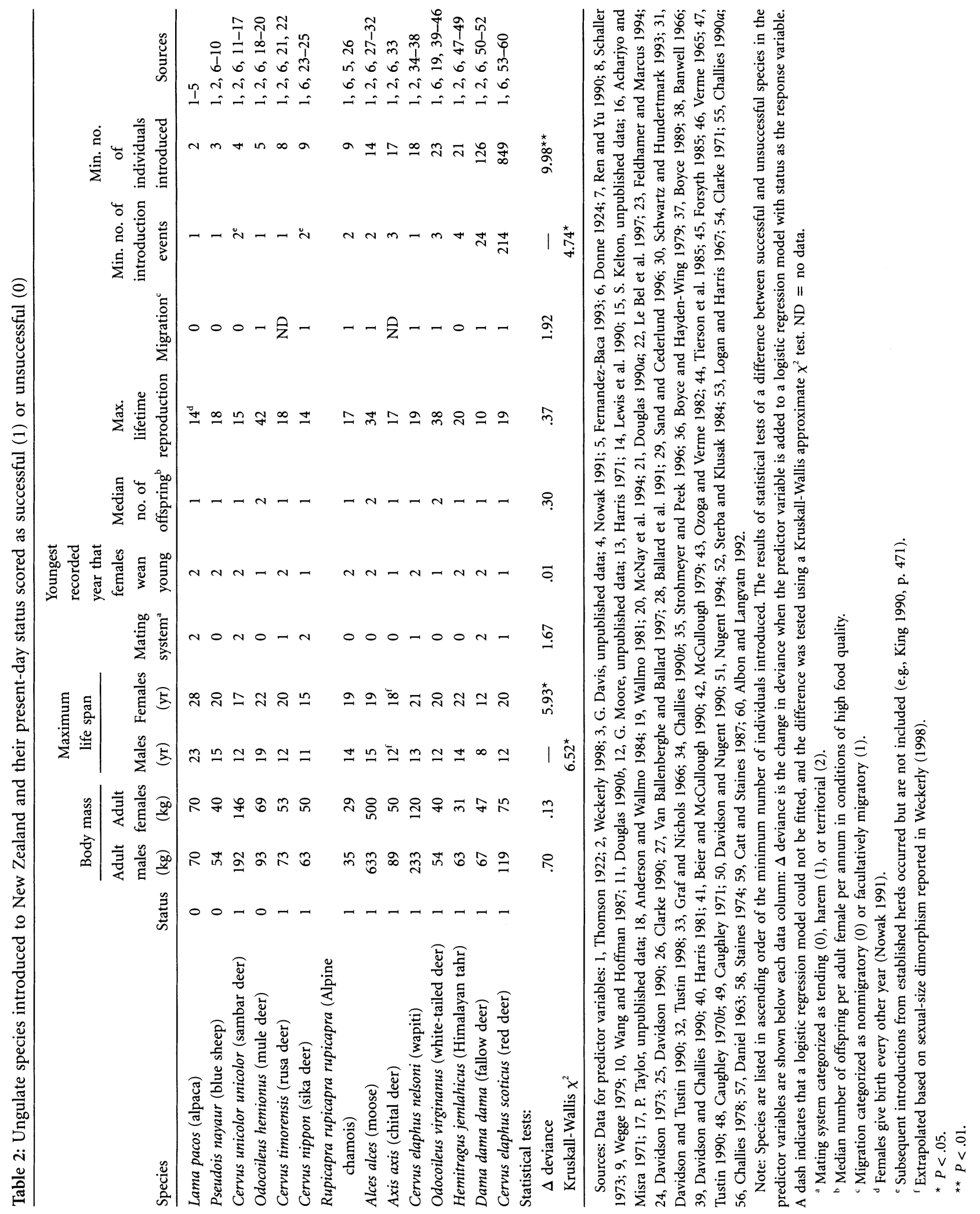




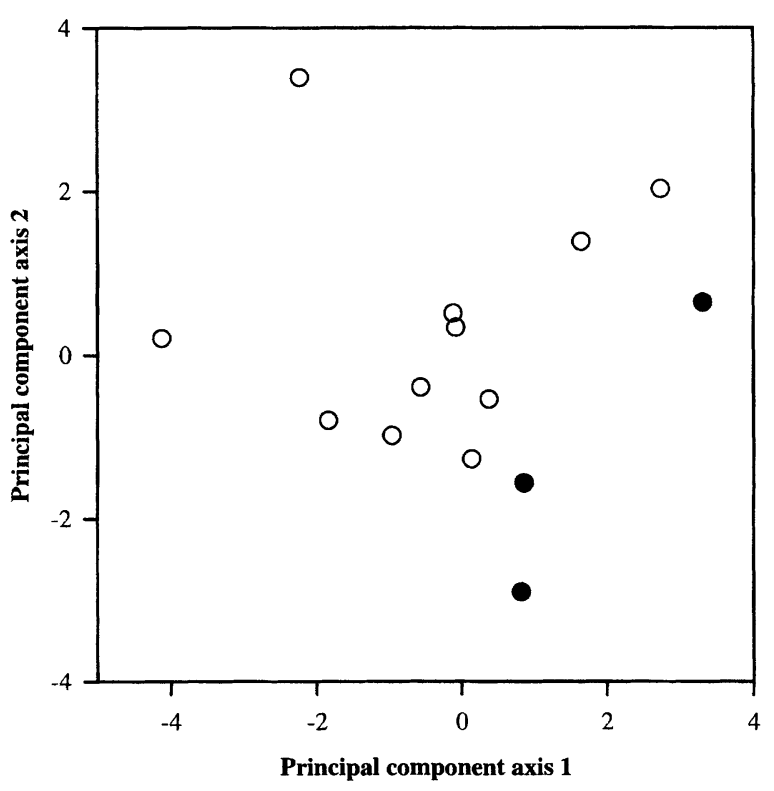

Figure 1: Plot of the first two axes from a principal components analysis using the traits in table 2 (excluding migration). Successfully introduced species are shown as open circles; unsuccessful species are shown as closed circles.

responsible for the success or failure of introductions (see "Results").

Introduction effort is a strong predictor of success for birds introduced to New Zealand (Veltman et al. 1996; Duncan 1997; Green 1997). We tested whether, for a given level of introduction effort, ungulates tended to be more or less successful than birds. To do this, we combined the data in Veltman et al. (1996) for the success of introduced birds, the number of introduction events, and the number of individuals introduced with our equivalent data for ungulates. Using logistic regression, we then tested whether the categorical variable taxonomic class (ungulate or bird) was a significant predictor of introduction success having adjusted for the number of introduction events and the number of individuals introduced.

\section{Results}

\section{Introduction Success of Ungulates}

Eleven of the 14 ungulate species were successfully introduced to New Zealand (table 2). Of the three unsuccessful species, none were apparently introduced into areas with unsuitable habitat (table 1), so we can tentatively exclude lack of suitable habitat as an explanation for their failure.

Three factors predicted whether introductions of ungulates succeeded (table 2). Species with greater maximum life spans and species that were introduced more often and in greater numbers were more likely to succeed. The first two principal components explained $53 \%$ of the total variation in the species traits listed in table 2 (excluding migration). Successful and unsuccessful species were separated along these first two axes (fig. 1); unsuccessful species occurred toward the lower right of the ordination, with higher axis 1 and lower axis 2 scores. Axis 1 separated species along a gradient of maximum life span, number of offspring per adult female, maximum lifetime reproduction, mating system (tending or not), and introduction effort (number of introduction events and number of individuals introduced). Axis 2 separated species along a gradient of introduction effort (table 3). Hence, successful species tended to have a shorter maximum life span, a lower number of offspring per adult female, lower maximum lifetime reproduction, were nontending, and were introduced more often and in greater numbers.

\section{Within-species Variation in Ungulate Introduction Effort}

Introduction effort was significantly related to introduction success across-species, but this relationship was confounded with other life-history traits. For example, the total number of individuals introduced and maximum male life span both significantly predicted introduction success (table 2), but these two variables were themselves correlated ( $r=-0.59, n=14, P=.028)$. We therefore examined whether independent introductions of the same

Table 3: Correlations of trait values with scores on the first two principal component axes for the 14 species of ungulates introduced to New Zealand

\begin{tabular}{lcc}
\hline Trait & Axis 1 & Axis 2 \\
\hline Body mass of adult males & .224 & .466 \\
Body mass of adult females & .267 & .365 \\
Maximum life span of males & $.753^{* *}$ & -.338 \\
Maximum life span of females & $.662^{\star *}$ & -.180 \\
Mating system: & & \\
$\quad$ Tending & $.685^{* *}$ & .093 \\
$\quad$ Harem & -.269 & .398 \\
$\quad$ Territorial & -.513 & -.464 \\
Youngest year that females wean & -.065 & -.480 \\
Number of offspring per female per & & \\
$\quad$ annum & $.714^{* *}$ & .459 \\
Maximum life time reproduction & $.833^{* * *}$ & .485 \\
Minimum number of introduction events & $-.598^{*}$ & $.620^{*}$ \\
Minimum number of individuals & & \\
$\quad$ introduced & $-.540^{*}$ & $.768^{* *}$ \\
\hline$* P<.05$. & & \\
&
\end{tabular}




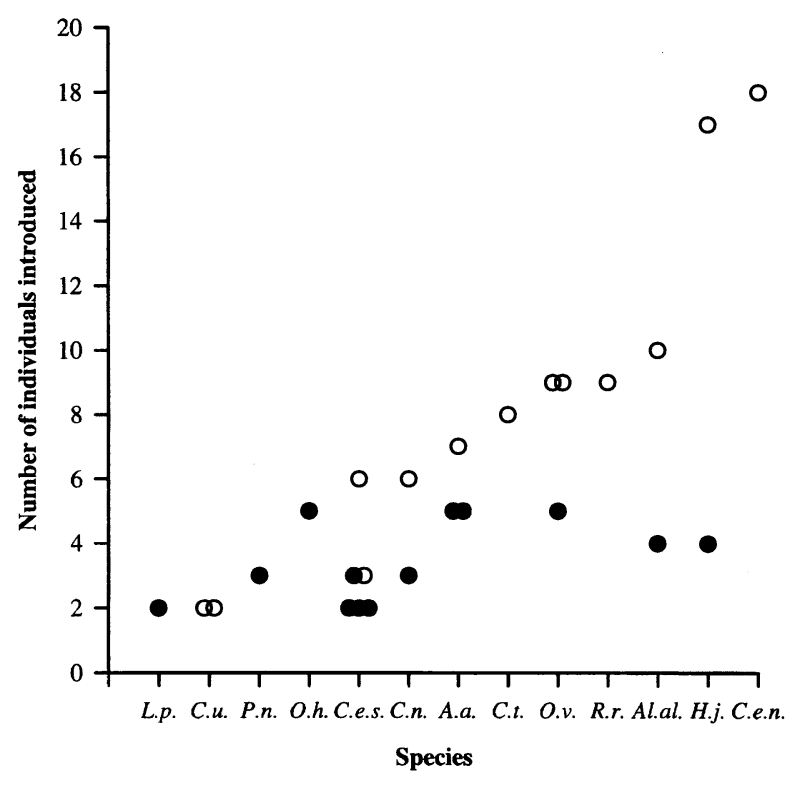

Figure 2: Relationship between the number of individuals introduced and introduction success for independent introductions of ungulate species to New Zealand. Successful introductions are shown as open circles, unsuccessful introductions as closed circles. Data for Cervus elaphus scoticus (red deer) are available for only a small subsample of introductions (Clarke 1971); red deer propagules of greater than six individuals were apparently always successful (Logan and Harris 1967). Two data points include more than one introduction event; Hemitragus jemlahicus was successful from three separate introductions at the same site in 1904 (five individuals), 1909 (eight), and 1919 (four), and Rupicapra rupicapra was successful from two separate introductions at the same site in 1907 (eight individuals) and 1914 (one female). Species are shown in ascending order of maximum propagule size: L.p. = Lama pacos; C.u. = Cervus unicolor unicolor; P.n. $=$ Pseudois nayaur; O.h. $=$ Odocoileus hemionus; C.e.s. $=$ C. elaphus scoticus; C.n. $=$ Cervus nippon; A.a. $=$ Axis axis; C.t. $=$ Cervus timorenis; O.v. $=$ Odocoileus virginianus; $R . r .=$ R. rupicapra rupicapra; Al.al. $=$ Alces alces; $H . j .=H$. jemlahicus; C.e.n. $=$ Cervus elaphus nelsoni.

species were more likely to succeed when a greater number of individuals were introduced.

For five of the six species with both successful and unsuccessful introductions, the successful introductions always involved more individuals than the unsuccessful introductions (fig. 2). Only for red deer (Cervus elaphus scoticus) was there a mixed outcome, where introductions of three individuals both succeeded and failed. For all of the independent introductions shown in figure 2, there was a highly significant relationship between the number of individuals introduced and introduction success (logistic regression, $\Delta$ deviance $=12.0, \mathrm{df}=1, P<.001$ ). All 10 introductions involving six or more individuals succeeded while 13 of the 16 introductions involving fewer than six individuals failed. This suggests there was a thresh- old introduction size of about six individuals, below which ungulate introductions to New Zealand were likely to fail and above which they were likely to succeed.

\section{Ungulates and Birds}

Among species introduced to New Zealand for which propagule size data are available, ungulates were relatively more successful (11 of 14 established, 79\%) than birds (29 of 79 established, 34\%; Veltman et al. 1996). Our finding, that the number of individuals introduced was a significant predictor of ungulate introduction success, parallels the finding for introduced New Zealand birds (Veltman et al. 1996; Duncan 1997; Green 1997). We ask whether, for a given level of introduction effort, ungulates were more or less likely to succeed than birds.

For birds and ungulates combined, the number of introduction events, the number of individuals introduced, and taxonomic class were all significant predictors of introduction success when included alone in a logistic regression model (table 4). Taxonomic class was an even stronger predictor after controlling for introduction effort, and there was no significant interaction between either measure of introduction effort and taxonomic class. Ungulates were therefore much more likely than birds to establish when introduced to New Zealand in low numbers (fig. 3).

Table 4: Results of logistic regression models with introduction success as the response variable and the two pairs of variables in the left-hand column as predictors, using the data for birds and ungulates introduced to New Zealand

\begin{tabular}{llll}
\hline Variable & $\mathrm{df}$ & Alone & Last \\
\hline $\begin{array}{l}\text { Introduction events: } \\
\quad \log _{10} \text { number of introduction } \\
\quad \text { events }\end{array}$ & 1 & $33.8^{* * *}$ & $55.1^{* * *}$ \\
$\quad \begin{array}{l}\text { Taxonomic class (bird or } \\
\quad \text { ungulate) }\end{array}$ & 1 & $9.8^{* *}$ & $31.1^{* * *}$ \\
$\begin{array}{l}\text { Individuals introduced: } \\
\quad \text { Log }_{10} \text { number of individuals } \\
\quad \text { introduced }\end{array}$ & 1 & $30.0^{* * *}$ & $47.1^{* * *}$ \\
$\quad \begin{array}{l}\text { Taxonomic class (bird or } \\
\text { ungulate) }\end{array}$ & 1 & $9.8^{* *}$ & $26.3^{* * *}$ \\
\hline
\end{tabular}

Note: "Alone" shows the change in deviance when each predictor variable was added to the model alone. "Last" shows the change in deviance when a predictor variable was added to the model after a second predictor variable (the alternative of the pair) was already included. $\mathrm{df}=$ number of degrees of freedom. $N=93$ for the number of introduction events, $N$ $=90$ for the number of individuals introduced.

** $P<.01$.

*** $P<.001$ 


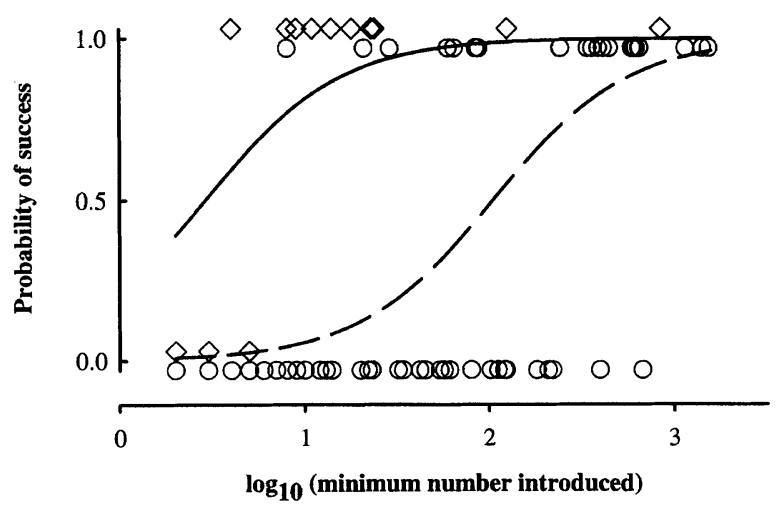

Figure 3: Relationship between introduction effort (measured as $\log _{10}$ minimum number of individuals introduced) and introduction success for 14 ungulate species (diamonds; three unsuccessful, 11 successful) and 76 bird species (circles; 51 unsuccessful, 25 successful) introduced to New Zealand and the logistic regression lines modeling the probability of success (solid line $=$ ungulates, dashed line $=$ birds).

\section{Discussion}

Despite the small sample size, our results (both across and within species) suggest that introduction effort, particularly the number of individuals introduced, was an important determinant of the success of ungulate introductions to New Zealand. We excluded two species (a "South American deer" and Lama glama) from our analyses because there was no data on the number of introduction events or the number of individuals introduced. This lack of information most likely reflects a low introduction effort. Both species were unsuccessful, and their inclusion, if we knew their details, would almost certainly reinforce our finding that species introduced in fewer numbers were less likely to succeed.

Both theoretical (Lande 1993, 1998) and empirical studies (Crowell 1973; Ebenhard 1989; Griffith et al. 1989; Berger 1990; Tracy and George 1992) have shown that the probability of extinction increases with decreasing population size, and our results further support this pattern (fig. 2). However, few individuals were required to establish ungulate populations. Of the independent introductions we considered, all of those with six or more individuals succeeded (fig. 2), and in two instances, populations of sambar deer (Cervus unicolor unicolor) established following the introduction of only a single pair (Harris 1971; King 1990).

The comparison of ungulate and bird introductions suggests that taxa vary with regard to the minimum number of individuals required for introductions to have a high chance of success. For a given number of individuals introduced, ungulates were much more likely to succeed than birds (table 4; fig. 3). This outcome parallels the findings of Griffith et al. (1989) and Wolf et al. (1996), who showed that, having controlled for other variables, including introduction effort, mammals translocated for conservation purposes were more likely to establish populations than translocated birds. Wolf et al. (1998) subsequently reanalyzed these data using the method of independent contrasts to control for phylogenetic relatedness and found no difference in the success rate of mammal and bird translocations. However, controlling for phylogenetic relatedness is unnecessary if the aim is to compare the success rate of introductions in two monophyletic groups. Our results and those of Wolf et al. (1996) therefore reveal a consistent difference in the relative success of mammal and bird introductions.

Several factors could explain the greater success rate of ungulates relative to birds for a given introduction effort in New Zealand. First, more care may have been taken with ungulate introductions. Agencies responsible for the introduction of ungulates apparently matched species with suitable habitat on all but one occasion (table 1) while bird introductions appeared to be more haphazard (Thomson 1922). Second, introduced ungulates lacked both predators and competitors while birds did not. Except for humans, ungulate predators were absent from New Zealand whereas birds faced a suite of indigenous and introduced avian predators plus three species of mustelid, three species of rat, and feral cats (King 1984, 1990). Ungulates also initially faced few potential competitors because native species, such as moa, had been extirpated (Caughley 1989), and because different species were rarely introduced to the same location. Even when more than one species of ungulate was introduced to the same location, the effects of competition became important only when one species attained high density (e.g., Himalayan tahr and Alpine chamois; Forsyth and Hickling 1998), long after the introduction might have failed for other reasons. There is little evidence that introduced birds compete to any extent with native birds in New Zealand (Diamond and Veitch 1981), but birds were often introduced to the same location and competition between introduced birds has been implicated as a factor increasing extinction rates following avian introductions on other islands (e.g., Moulton and Pimm 1987; Moulton and Lockwood 1992; but see Simberloff and Boecklen 1991). Third, ungulates, and mammals in general, differ from birds in aspects of their life history (Gaillard et al. 1989) that could influence introduction outcomes. In particular, the survival rate for adult ungulates is higher and perhaps more constant (Gaillard et al. 1998) than for birds (Sæther 1989; Karr et al. 1990), so that small populations of long-lived mammals should be more strongly buffered against demographic stochasticity (Legendre et al. 1999) and environmental extremes (Lindstedt and Boyce 1985). Likewise, the proportionately greater variance associated with the higher intrinsic 
rate of increase $\left(r_{\mathrm{m}}\right)$ of many small birds (Pimm et al. 1988) relative to ungulates (McCorquodale et al. 1988; Choquenot 1990) could place colonizing bird populations at greater risk of extinction (Leigh 1981; Lande 1993).

We conclude that introduction effort was a critical factor in the success of ungulate introductions to New Zealand. Our findings suggest that, if six or more individuals of the unsuccessful species had been introduced, then it is likely that they would have succeeded, given that they were introduced into suitable habitat. This finding applies also to bird introductions (Veltman et al. 1996; Duncan 1997; Green 1997), although more individuals of each species of bird would have to be introduced to achieve a success rate comparable with ungulates.

\section{Acknowledgments}

We thank G. Davis, J. L. Fox, B. Griffith, M. Harrison, S. Kelton, C. M. King, G. Moore, P. Taylor, and C. Wolf for providing us with references and/or unpublished information. J. P. Parkes noted the single case of "unsuitable" habitat. Comments by F. Cassirer, J. M. Gaillard, L. L. Manne, J. L. Ruesink, B.-E. Sæther, D. Simberloff, A. R. E. Sinclair, K. S. Smallwood, J. N. M. Smith, D. S. Srivastava, O. R. W. Sutherland, P. Syrett, C. J. Veltman, and an anonymous reviewer greatly improved the manuscript. We also thank T. Garland, B. Griffith, and C. Wolf for clarifying their phylogenetic analysis.

\section{Literature Cited}

Acharjyo, L. N., and R. Misra. 1971. Age of sexual maturity of three species of wild animals in captivity. Journal of the Bombay Natural History Society 68:446.

Albon, S. D., and R. Langvatn. 1992. Plant phenology and the benefits of migration in a temperate ungulate. Oikos 65:502-513.

Anderson, A. E., and O. C. Wallmo. 1984. Odocoileus heimonus. Mammalian Species 219:1-9.

Ballard, W. B., J. S. Whitman, and D. J. Reed. 1991. Population dynamics of moose in south-central Alaska. Wildlife Monographs 114:1-49.

Banwell, D. B. 1966. Wapiti in New Zealand. Reed, Wellington.

Bauer, J. J. 1990. The analysis of plant-herbivore interactions between ungulates and vegetation on alpine grasslands in the Himalayan region of Nepal. Vegetatio 90:15-34.

Beier, P., and D. R. McCullough. 1990. Factors influencing white-tailed deer activity patterns and habitat use. Wildlife Monographs 109:1-51.

Beirne, B. P. 1975. Biological control attempts by introductions against pest insects in the field in Canada. Canadian Entomologist 107:225-236.
Berger, J. 1990. Persistence of different-sized populations: an empirical assessment of rapid extinctions in bighorn sheep. Conservation Biology 4:91-98.

Berggren, Å. 2001. Colonization success in Roesel's bush cricket Matrioptera roeseli: the effects of propagule size. Ecology 82:274-280.

Bhat, S. D., and G. S. Rawat. 1995. Habitat use by chital (Axis axis) in Dhaulkhand, Rajaji National Park, India. Tropical Ecology 36:177-189.

Blaschke, P. M., G. G. Hunter, G. O. Eyles, and P. R. van Berkel. 1981. Analysis of New Zealand's vegetation cover using land resource inventory data. New Zealand Journal of Ecology 4:1-119.

Boyce, M. S. 1989. The Jackson elk herd: intensive wildlife management in North America. Cambridge University Press, Cambridge.

Boyce, M. S., and L. D. Hayden-Wing. 1979. American elk: ecology, behavior and management. University of Wyoming Press, Laramie.

Catt, D. C., and B. W. Staines. 1987. Home range use and habitat selection by red deer (Cervus elaphus) in a Sitka spruce plantation as determined by radio-tracking. Journal of Zoology (London) 211:681-693.

Caughley, G. 1970a. Habitat of the Himalayan tahr Hemitragus jemlahicus. Journal of the Bombay Natural History Society 67:103-105.

- 1970b. Liberation, dispersal and distribution of Himalayan tahr (Hemitragus jemlahicus) in New Zealand. New Zealand Journal of Science 13:220-239.

-1971. The season of births for northern-hemisphere ungulates in New Zealand. Mammalia 35:204-219.

. 1989. New Zealand plant-herbivore systems: past and present. New Zealand Journal of Ecology 12:3-10.

Caughley, G., and C. Krebs. 1983. Are big mammals simply little mammals writ large? Oecologia (Berlin) 59:7-17.

Chadwick, A. H., P. R. Ratcliffe, and K. Abernethy. 1996. Sika deer in Scotland: density, population size, habitat use and fertility-some comparisons with red deer. Scottish Forestry 50:8-16.

Challies, C. N. 1978. Assessment of the physical well-being of red deer (Cervus elaphus L.) populations in South Westland, New Zealand. Ph.D. diss. University of Canterbury, Christchurch.

- 1990a. Red deer. Pages 436-458 in C. M. King, ed. The handbook of New Zealand mammals. Oxford University Press, Auckland.

- 1990b. Wapiti. Pages 458-467 in C. M. King, ed. The handbook of New Zealand mammals. Oxford University Press, Auckland.

Chapman, D., and N. Chapman. 1975. Fallow deer: their history, distribution and biology. Dalton, Lavenham. Choquenot, D. 1990. Rate of increase for populations of 
feral donkeys in northern Australia. Journal of Mammalogy 71:151-155.

Clarke, C. M. H. 1971. Liberations and dispersal of red deer in northern South Island districts. New Zealand Journal of Forestry Science 1:194-207.

- 1990. Chamois. Pages 380-391 in C. M. King, ed. The handbook of New Zealand mammals. Oxford University Press, Auckland.

Clutton-Brock, T. H., and S. D. Albon. 1989. Red deer in the highlands. BSP Professional, Oxford.

Collett, D. 1991. Modelling binary data. Chapman \& Hall, London.

Crawley, M. J. 1987. What makes a community invasible? Pages 429-453 in A. J. Gray, M. J. Crawley, and P. J. Edwards, eds. Colonization, succession and stability. Blackwell Scientific, Oxford.

Crowell, K. L. 1973. Experimental zoogeography: introductions of mice to small islands. American Naturalist 107:535-558.

Daniel, M. J. 1963. Early fertility of red deer hinds in New Zealand. Nature (London) 200:380.

Davidson, M. M. 1973. Characteristics, liberation and dispersal of sika deer (Cervus nippon) in New Zealand. New Zealand Journal of Forestry Science 3:153-180.

1990. Sika deer. Pages 468-477 in C. M. King, ed. The handbook of New Zealand mammals. Oxford University Press, Auckland.

Davidson, M. M., and C. N. Challies. 1990. White-tailed deer. Pages 507-514 in C. M. King, ed. The handbook of New Zealand mammals. Oxford University Press, Auckland.

Davidson, M. M., and G. Nugent. 1990. Fallow deer. Pages 490-506 in C. M. King, ed. The handbook of New Zealand mammals. Oxford University Press, Auckland.

Davidson, M. M., and K. G. Tustin. 1990. Moose. Pages 514-520 in C. M. King, ed. The handbook of New Zealand mammals. Oxford University Press, Auckland.

Diamond, J. M., and C. R. Veitch. 1981. Extinctions and introductions in the New Zealand avifauna: cause and effect? Science (Washington, D.C.) 211:499-501.

Donne, T. E. 1924. The game animals of New Zealand. J. Murray, London.

Douglas, M. J. W. 1990a. Rusa deer. Pages 483-488 in C. M. King, ed. The handbook of New Zealand mammals. Oxford University Press, Auckland.

- 1990b. Sambar deer. Pages 477-483 in C. M. King, ed. The handbook of New Zealand mammals. Oxford University Press, Auckland.

Drake, J. A., H. A. Mooney, F. di Castri, R. H. Groves, F. J. Kruger, M. Rejmánek, and M. Williamson. 1989. Biological invasions: a global perspective. Wiley, Chichester.

Duncan, R. P. 1997. The role of competition and introduction effort in the success of passeriform birds in- troduced to New Zealand. American Naturalist 149: 903-915.

Ebenhard, T. 1989. Bank vole [Clethrionomys glareolus (Schreber, 1780)] propagules of different sizes and island colonization. Journal of Biogeography 16:173-180.

Ehler, L. E., and R. W. Hall. 1982. Evidence for competitive exclusion of introduced natural enemies in biological control. Environmental Entomology 11:1-4.

Elton, C. S. 1958. The ecology of invasions by plants and animals. Chapman \& Hall, London.

Endo, A., and T. Doi. 1996. Home range of female sika deer Cervus nippon on Nozaki Island, the Goto Archipelago, Japan. Mammal Study 21:27-35.

Feldhamer, G. A., and M. A. Marcus. 1994. Reproductive performance of female sika deer in Maryland. Journal of Wildlife Management 58:670-673.

Fernandez-Baca, S. 1993. Manipulation of reproductive functions in male and female New World camelids. Animal Reproduction Science 33:307-323.

Forsyth, A. 1985. Mammals of the American north. Camden House, Camden East.

Forsyth, D. M., and G. J. Hickling. 1998. Increasing Himalayan tahr and decreasing chamois densities in the eastern Southern Alps, New Zealand: evidence for interspecific competition. Oecologia (Berlin) 113:377-382.

Franklin, W. L. 1982. Biology, ecology, and relationship to man of the South American camelids. Special publication series, Pymatuning Laboratory of Ecology no. 6, pp. 457-489.

Franzmann, A. W., and C. C. Schwartz. 1997. Ecology and management of the North American moose. Smithsonian Institution, Washington, D.C.

Gaillard, J.-M., D. Pontier, D. Allainé, J. D. Lebreton, J. Trouvilliez, and J. Clobert. 1989. An analysis of demographic tactics in birds and mammals. Oikos 56:59-76.

Gaillard, J.-M., M. Festa-Bianchet, and N. G. Yoccoz. 1998. Population dynamics of large herbivores: variable recruitment with constant adult survival. Trends in Ecology \& Evolution 13:58-63.

Georgii, B. 1980. Home range patterns of female red deer (Cervus elaphus L.) in the Alps. Oecologia (Berlin) 47: 278-285.

Goel, N. S., and N. Richter-Dyn. 1974. Stochastic models in biology. Academic Press, New York.

Goodman, D. 1987. The demography of chance extinction. Pages 11-43 in M. E. Soulé, ed. Viable populations for conservation. Cambridge University Press, New York.

Graf, W., and L. Nichols, Jr. 1966. The axis deer in Hawaii. Journal of the Bombay Natural History Society 63: 629-734.

Green, R. E. 1997. The influence of numbers released on the outcome of attempts to introduce exotic bird species to New Zealand. Journal of Animal Ecology 66:25-35. 
Griffith, B., J. M. Scott, J. W. Carpenter, and C. Reed. 1989. Translocation as a species conservation tool: status and strategy. Science (Washington, D.C.) 245:477-480.

Halls, L. K. 1984. White-tailed deer ecology and management. Wildlife Management Institute, Washington, D.C.

Hanson, F. B., and H. C. Tuckwell. 1978. Persistence times of populations with large random fluctuations. Theoretical Population Biology 14:46-61.

Harris, L. H. 1971. Notes on the introduction and history of sambar deer in New Zealand. New Zealand Wildlife 35:33-42.

. 1981. White-tailed deer in New Zealand. New Zealand Wildlife 64(suppl.):1-12.

Harris, R. B., and D. J. Miller. 1995. Overlap in summer habitats and diets of Tibetan Plateau ungulates. Mammalia 59:197-212.

Harvey, P. H., and M. Pagel. 1991. The comparative method in evolutionary biology. Oxford University Press, Oxford.

Hopper, K. R., and R. T. Roush. 1993. Mate finding, dispersal, number released, and the success of biological control introductions. Ecological Entomology 18: 321-331.

Karr, J. R., J. D. Nichols, M. K. Klimkiewicz, and J. D. Brawn. 1990. Survival rates of birds of tropical and temperate forests: will the dogma survive? American Naturalist 136:277-291.

Khan, J. A. 1994. Food habits of ungulates in dry tropical forests of Gir Lion Sanctuary, Gujarat, India. Acta Theriologica 39:185-193.

King, C. M. 1984. Immigrant killers. Oxford University Press, Auckland.

—, ed. 1990. The handbook of New Zealand mammals. Oxford University Press, Auckland.

Komers, P. E., and C. P. Curman. 2000. The effect of demographic characteristics on the success of ungulate re-introductions. Biological Conservation 93:187-193.

Krementz, D. G., J. R. Sauer, and J. D. Nichols. 1989. Model-based estimates of annual survival are preferable to observed maximum life span statistics for use in comparative life-history studies. Oikos 56:203-208.

Lande, R. 1988. Genetics and demography in biological conservation. Science (Washington, D.C.) 241:1455-1460.

1993. Risks of population extinction from demographic and environmental stochasticity and random catastrophes. American Naturalist 142:911-927.

- 1998. Demographic stochasticity and Allee effect on a scale with isotropic noise. Oikos 83:353-358.

Lawton, J. H., and K. C. Brown. 1986. The population and community ecology of invading insects. Philosophical Transactions of the Royal Society of London B, Biological Sciences 314:607-617.

Le Bel, S., M. Salas, P. Chardonnet, and M. Bianchi. 1997. Rusa deer (Cervus timorensis russa) farming in New Zea- land: impact of different feed levels on herd breeding rate and performance of newborn fawns. Australian Veterinary Journal 75:199-203.

Legendre, S., J. Clobert, A. P. Møller, and G. Sorci. 1999. Demographic stochasticity and social mating system in the process of extinction of small populations: the case of passerines introduced to New Zealand. American Naturalist 153:449-463.

Leigh, E. G. 1981. The average lifetime of a population in a varying environment. Journal of Theoretical Biology 90:231-239.

Lever, C. 1994. Naturalized animals. Cambridge University Press, Cambridge.

Lewis, J. C., L. B. Flynn, R. L. Marchinton, S. M. Shea, and E. M. Marchinton. 1990. Biology of sambar deer on St. Vincent National Wildlife Refuge, Florida. Tall Timbers Research Station Bulletin 25:1-107.

Lindstedt, L. S., and M. S. Boyce. 1985. Seasonality, fasting endurance, and body size in mammals. American Naturalist 125:873-878.

Lockwood, J. L., and M. P. Moulton. 1994. Ecomorphological pattern in Bermuda birds: the influence of competition and implications for nature preserves. Evolutionary Ecology 8:53-60.

Lockwood, J. L., M. P. Moulton, and S. K. Anderson. 1993. Morphological assortment and the assembly of communities of introduced passerines on oceanic islands: Tahiti versus Oahu. American Naturalist 141:398-408.

Lodge, D. M. 1993. Biological invasions: lessons for ecology. Trends in Ecology \& Evolution 8:133-137.

Logan, P. C., and L. H. Harris. 1967. Introduction and establishment of red deer in New Zealand. New Zealand Forest Service Information Series 55:1-36.

Long, J. L. 1981. Introduced birds of the world. David \& Charles, London.

Lovegrove, T. G. 1996. Island releases of saddlebacks Philesturnus carunculatus in New Zealand. Biological Conservation 77:151-157.

McCorquodale, S. M., L. L. Eberhardt, and L. E. Eberhardt. 1988. Dynamics of a colonizing elk population. Journal of Wildlife Management 52:309-313.

McCullough, D. R. 1979. The George Reserve deer herd. University of Michigan Press, Ann Arbor.

- 1991. Long range movements of large terrestrial mammals. Contributions in Marine Science 27(suppl.): 444-465.

McLain, D. K., M. P. Moulton, and T. P. Redfearn. 1995. Sexual selection and the risk of extinction of introduced birds on oceanic islands. Oikos 74:27-34.

McNay, R. S., J. A. Morgan, and F. L. Bunnell. 1994. Characterizing independence of observations in movements of Columbian black-tailed deer. Journal of Wildlife Management 58:422-429. 
Memmott, J., S. V. Fowler, and R. L. Hill. 1998. The effect of release size on the probability of establishment of biological control agents: gorse thrips (Sericothrips staphylinus) released against gorse (Ulex europaeus) in New Zealand. Biocontrol Science and Technology 8:103-115.

Moe, S. R., and P. Wegge. 1994. Spacing behaviour and habitat use of axis deer (Axis axis) in lowland Nepal. Canadian Journal of Zoology 72:1735-1744.

Mooney, H. A., and J. A. Drake. 1986. Ecology of biological invasions of North America. Springer, Berlin.

Moulton, M. P. 1985. Morphological similarity and coexistence of congeners: an experimental test with introduced Hawaiian birds. Oikos 44:301-305.

Moulton, M. P., and J. L. Lockwood. 1992. Morphological dispersion of introduced Hawaiian finches: evidence for competition and a Narcissus effect. Evolutionary Ecology 6:45-55.

Moulton, M. P., and S. L. Pimm. 1987. Morphological assortment in introduced Hawaiian passerines. Evolutionary Ecology 1:113-124.

Novellie, P. A., and M. Knight. 1994. Repatriation and translocation of ungulates into South African national parks: an assessment of past attempts. Koedoe 37: 115-119.

Novellie, P. A., P. S. Millar, and P. H. Lloyd. 1996. The use of VORTEX simulation models in a long-term programme of re-introduction of an endangered large mammal, the Cape mountain zebra (Equus zebra zebra). Acta Oecologia 17:657-671.

Nowak, R. M. 1991. Walker's mammals of the world. Vol. 2. 5th ed. John Hopkins University Press, Baltimore.

Nugent, G. 1994. Home range size and its development for fallow deer in the Blue Mountains, New Zealand. Acta Theriologica 39:159-175.

Oli, M. K. 1996. Seasonal patterns in habitat use of blue sheep Pseudois nayaur (Artiodactyla, Bovidae) in Nepal. Mammalia 59:197-212.

Ozoga, J. J., and L. J. Verme. 1982. Physical and reproductive characteristics of a supplementally-fed whitetailed deer herd. Journal of Wildlife Management 46: 281-301.

Pimm, S. L. 1991. The balance of nature? University of Chicago Press, Chicago.

Pimm, S. L., H. L. Jones, and J. Diamond. 1988. On the risk of extinction. American Naturalist 132:757-785.

Porwal, M. C., P. S. Roy, and V. Chellamuthu. 1996. Wildlife habitat analysis for "sambar" (Cervus unicolor) in Kanha National Park using remote sensing. International Journal of Remote Sensing 17:2683-2697.

Putman, R. J. 1996. Competition and resource partitioning in temperate ungulate communities. Chapman \& Hall, London.

Ren, J., and Y. Yu. 1990. A study of the population struc- ture and life table of blue sheep in Yushu and Golog, Qinghai Province. Acta Theriologica Sinica 10:189-193.

Richter-Dyn, N., and N. S. Goel. 1972. On the extinction of a colonizing species. Theoretical Population Biology 3:406-433.

Ruesink, J. L., I. M. Parker, M. J. Groom, and P. M. Kareiva. 1995. Reducing the risks of nonindigenous species introductions. BioScience 45:465-477.

Ryan, P. G., and W. R. Siegfried. 1994. The viability of small populations of birds: an empirical investigation of vulnerability. Pages 3-22 in H. Remmert, ed. Minimum animal populations. Springer, Berlin.

Sæther, B.-E. 1989. Survival rates in relation to body weight in European birds. Ornis Scandinavica 20:13-21.

Sand, H., and G. Cederlund. 1996. Individual and geographc variation in age at maturity in female moose (Alces alces). Canadian Journal of Zoology 74:954-964.

Schaller, G. B. 1973. On the behaviour of blue sheep (Pseudois nayaur). Journal of the Bombay Natural History Society 69:523-537.

Schoener, T. W., and D. A. Spiller. 1992. Is extinction rate related to temporal variability in population size? an empirical answer for orb spiders. American Naturalist 139:1176-1207.

- 1995. Effect of predators and area on invasion: an experiment with island spiders. Science (Washington, D.C.) 267:1811-1813.

Schwartz, C. C., and K. J. Hundertmark. 1993. Reproductive characteristics of Alaskan moose. Journal of Wildlife Management 57:454-468.

Short, J., S. D. Bradshaw, J. Giles, R. I. T. Prince, and G. R. Wilson. 1992. Reintroduction of macropods (Marsupialia: Macropodoidea) in Australia: a review. Biological Conservation 62:189-204.

Simberloff, D., and W. Boecklen. 1991. Patterns of extinction in the introduced Hawaiian avifauna: a reexamination of the role of competition. American Naturalist 138:300-327.

Sorci, G., A. P. Møller, and J. Clobert. 1998. Plumage dichromatism of birds predicts introduction success in New Zealand. Journal of Animal Ecology 67:263-269.

Staines, B. W. 1974. A review of factors affecting deer dispersion and their relevance to management. Mammal Review 4:79-91.

Stearns, S. C. 1992. The evolution of life histories. Oxford University Press, Oxford.

Sterba, O., and K. Klusak. 1984. Reproductive biology of fallow deer, Dama dama. Acta Scientiarium Naturalium Academiae Scientiarium Bohemoslovacae Brno 18:1-46.

Stewart, J. W. F. 1985. Deer and development in Southwest Papua New Guinea. Pages 381-385 in K. R. Drew, ed. The biology of deer production. Royal Society of New Zealand, Wellington. 
Strohmeyer, D. C., and J. M. Peek. 1996. Wapiti home range and movement patterns in a sagebrush desert. Northwest Science 70:79-87.

Takatsuki, S. 1990. Summer dietary composition of sika deer on Yakushima Island, Southern Japan. Ecological Research 5:253-260.

Thomson, G. M. 1922. The naturalisation of animals and plants in New Zealand. Cambridge University Press, Cambridge.

Tierson, W. C., G. F. Mattfield, R. W. Sage, Jr., and D. F. Behrend. 1985. Seasonal movements and home ranges of white-tailed deer in the Adirondacks. Journal of Wildlife Management 49:760-769.

Tracy, C. R., and L. T. George. 1992. On the determinants of extinction. American Naturalist 139:102-122.

Tustin, K. G. 1990. Himalayan tahr. Pages 392-406 in C. M. King, ed. The handbook of New Zealand mammals. Oxford University Press, Auckland.

- 1998. A wild moose chase. Wild South, Dunedin.

Van Ballenberghe, V., and W. B. Ballard. 1997. Population dynamics. Pages 223-245 in A. W. Franzmann and C. C. Schwartz, eds. Ecology and management of the North American moose. Smithsonian Institution, Washington, D.C.

Veltman, C. J., S. Nee, and M. J. Crawley. 1996. Correlates of introduction success in exotic New Zealand birds. American Naturalist 147:542-557.

Verme, L. J. 1965. Reproduction studies on penned whitetailed deer. Journal of Wildlife Management 29:74-79.

Von Elsner-Schack, I. 1985. What is good chamois habitat?
Pages 71-76 in S. Lovari, ed. The biology and management of mountain ungulates. Croom Helm, London.

Wallmo, O. C. 1981. Mule and black-tailed deer of North America. University of Nebraska Press, Lincoln.

Wang, X., and R. S. Hoffman. 1987. Pseudois nayaur and Pseudois schaeferi. Mammalian Species 278:1-6.

Weckerly, F. W. 1998. Sexual-size dimorphism: influence of mass and mating systems in the most dimorphic mammals. Journal of Mammalogy 79:33-52.

Wegge, P. 1979. Aspects of the population ecology of blue sheep in Nepal. Journal of Asian Ecology 1:10-20.

Whitehead, G. K. 1972. Deer of the world. Constable, London.

Williamson, M. 1996. Biological invasions. Chapman \& Hall, London.

Williamson, M., and A. Fitter. 1996. The varying success of invaders. Ecology 77:1661-1666.

Wilson, P. 1981. Ecology and habitat utilisation of blue sheep Pseudois nayaur in Nepal. Biological Conservation 21:55-74.

Wolf, C. M., B. Griffith, C. Reed, and S. A. Temple. 1996. Avian and mammalian translocations: update and reanalysis of 1987 survey data. Conservation Biology 10: 1142-1154.

Wolf, C. M., T. Garland, Jr., and B. Griffith. 1998. Predictors of avian and mammalian translocation success: reanalysis with phylogenetically independent contrasts. Biological Conservation 86:243-255.

Associate Editor: Daniel Simberloff 